\title{
Effects of yeast (Saccharomyces cerevisiae type boulardii CNCM I-1079) supplementation on growth performance and blood metabolites in Black Bengal goat kids
}

\author{
Sudeb Saha ${ }^{1,2}$, Somir Singha ${ }^{1}$, Syed S. U. Ahmed ${ }^{3}$, \\ Hugo Toledo-Alvarado ${ }^{2}$, and Mohammad M. H. Khan ${ }^{4 *}$ \\ ${ }^{I}$ Department of Dairy Science, Faculty of Veterinary, Animal and Biomedical Sciences, Sylhet Agricultural \\ University, Sylhet, Bangladesh \\ ${ }^{2}$ Department of Agronomy, Food, Natural Resources, Animals and Environment (DAFNAE), University of \\ Padova, Legnaro, Italy \\ ${ }^{3}$ Department of Epidemiology and Public Health, Faculty of Veterinary, Animal and Biomedical Sciences, \\ Sylhet Agricultural University, Sylhet, Bangladesh \\ ${ }^{4}$ Department of Biochemistry and Chemistry, Faculty of Biotechnology and Genetic Engineering, Sylhet \\ Agricultural University, Sylhet, Bangladesh
}

SAHA, S., S. SINGHA, S. S. U. AHMED, H. TOLEDO-ALVARADO, M. M. H. KHAN: Effects of yeast (Saccharomyces cerevisiae type boulardii CNCM I-1079) supplementation on growth performance and blood metabolites in Black Bengal goat kids. Vet. arhiv 88, 661-672, 2018.

\section{ABSTRACT}

The objective of this study was to investigate the effects of yeast (Saccharomyces cerevisiae type boulardii CNCM I-1079) supplementation on growth performance and blood metabolites in Black Bengal goat kids. The experiment was performed on eight growing Black Bengal goat kids divided into a control diet (CD) group without yeast and yeast supplement (YS) group with $1.5 \%$ of yeast supplement. The feeding experiment was conducted for 40 days with growth performance measured every ten days, and blood samples were collected on days 0 and 40 of the experiment. The data were analyzed using a mixed model. The results showed that YS had no effect on growth parameters. Moreover, addition of yeast to the diet did not affect the blood parameters (phosphorus (P), cholesterol, triacylglycerol, urea, total protein, glutamate pyruvate transaminase (GPT), and glutamate oxaloacetate transaminase (GOT)) except calcium $(\mathrm{Ca})$ and magnesium $(\mathrm{Mg})$. In the YS group animals, a slight increase in blood level concentration of $\mathrm{Ca}$ and $\mathrm{Mg}$ was observed compared to the $\mathrm{CD}$ group.

Key words: Saccharomyces cerevisiae type boulardii; growth parameters; blood parameters; goat kids

\footnotetext{
*Corresponding author:

Mohammad M. H. Khan, Department of Biochemistry and Chemistry, Faculty of Biotechnology and Genetic Engineering, Sylhet Agricultural University, Sylhet-3100, Bangladesh, Phone: +88 0168059 2166; E-mail: mehedi2001bdbd@gmail.com
} 
S. Saha et al.: Effects of yeast (Saccharomyces cerevisiae type boulardii CNCM I-1079) supplementation on growth performance and blood metabolites in Black Bengal goat kids

\section{Introduction}

Goat production in Bangladesh is an integral part of many farming systems. Of the 20.6 million goat population in Bangladesh, more than $90 \%$ are of the Black Bengal breed (SULTANA et al., 2012). Black Bengal goats are popular for meat production as they are highly prolific (twins or triplets are common in kidding), gain body weight rapidly and reach slaughter size very quickly (AMIN et al., 2000). Black Bengal goats are relatively low maintenance animals and suitable for rearing in a low input backyard production system. The demand for Black Bengal goat meat, milk and skin is very high. Thus, Black Bengal goat farming is becoming increasingly popular in Bangladesh. However, to meet the increased demand for Black Bengal goat products, large-scale semi-intensive and intensive farming is gradually replacing the small-scale backyard production system. In an intensive system, feed plays a significant role in attaining desirable and high production performance. Also, for the Black Bengal goat producers improving growth performance is an important production trait for the profitability of their farming. Dietary supplementation may improve growth performance of animals. The motivation for improving the growth performance of goats using natural dietary supplements comes from producer demand, as well as consumer demand for synthetic growth promoter free goat meat (TITI et al., 2008). Thus, dietary yeast supplement may be an important candidate for improving the growth performance of animals (HILLAL et al., 2011).

Saccharomyces cerevisiae is an important type of yeast used in ruminant nutrition. S. cerevisiae yeast enhances animal productivity and delivers health benefits, probably through the establishment of a healthy gastrointestinal tract (MILEWSKI, 2009; DOBICKI et al., 2007). Thus, several studies have been conducted to determine the efficiency of yeast supplementation (YS) in ruminant diets, but the results are variable. CABRERA et al. (2000) reported no effect of yeast culture on dry matter (DM) intake, live weight gain or feed conversion ratio in steers. WEHNER et al. (1998) described that calves gained more weight with YS, but the differences were not significant. Likewise, YS did not affect the daily weight gain of lambs (AHMED et al., 2015; KAWAS et al., 2007). Previously, S. cerevisiae was used as a feed supplement in small ruminants, but knowledge about its effects is limited. Therefore, the objective of this study was to evaluate the effects of $S$. cerevisiae type boulardii supplement on the growth performance and blood metabolites of Black Bengal goat kids.

\section{Materials and methods}

Animals and diets. This study was conducted at the Goat Development Farm, Sylhet Agricultural University (Bangladesh), from the period from March to May 2016. The animals used in this experiment were cared for under the guidelines of the Faculty of Veterinary and Animal Science regulations for care and treatment of animals at the 
S. Saha et al.: Effects of yeast (Saccharomyces cerevisiae type boulardii CNCM I-1079) supplementation on growth performance and blood metabolites in Black Bengal goat kids

university. A total of eight female Black Bengal growing kids aged five months, with similar body weights (CD group: $9.40 \pm 1.08 \mathrm{~kg}$ and YS group: $8.83 \pm 0.96 \mathrm{~kg}$ ) were randomly assigned into two groups (4 animals each) with two different dietary treatments, for $\mathrm{CD}$ (control diet) and YS (Yeast supplement - 1.5\% yeast supplemented).

Table 1. Ingredients and chemical composition of concentrate and German grass for control diet (CD) and yeast supplemented diet (YS)

\begin{tabular}{|l|c|c|}
\hline Concentrate feeds (\% of total weight) & CD & YS \\
\hline Wheat bran & 20 & 19.7 \\
\hline Kheshari bran & 37 & 36.4 \\
\hline Broken wheat & 15 & 14.8 \\
\hline Broken chickpea & 10 & 9.8 \\
\hline Soyabean meal & 15 & 14.8 \\
\hline Di-calcium phosphate (DCP) & 1.5 & 1.5 \\
\hline Vitamin - DB & 0.5 & 0.5 \\
\hline Salt & 1 & 1 \\
\hline Yeast & N/A & 1.5 \\
\hline Total & 100 & 100 \\
\hline Chemical composition of concentrate feeds (\%) & CD & YD \\
\hline DM & 86.56 & 85.56 \\
\hline CP & 19.50 & 22.75 \\
\hline NDF & 53.24 & 56.21 \\
\hline ADF & 42.15 & 39.54 \\
\hline EE & 3.19 & 3.41 \\
\hline ASH & 7.51 & 5.96 \\
\hline German grass chemical composition & \multicolumn{2}{|c|}{$(\%)$} \\
\hline DM & \multicolumn{2}{|c|}{21.6} \\
\hline CP & \multicolumn{2}{|c|}{14.97} \\
\hline NDF & 13.5 \\
\hline ADF & \\
\hline EE & \multicolumn{2}{|c|}{} \\
\hline ASH & \\
\hline D & \multicolumn{2}{|c|}{} \\
\hline
\end{tabular}

$\mathrm{DM}=$ Dry matter; $\mathrm{CP}=$ Crude protein; $\mathrm{NDF}=$ Neutral detergent fiber $(\mathrm{NDF}) ; \mathrm{ADFA}=$ acid detergent fiber; $\mathrm{EE}$ $=$ Ether extract.

Yeast was mixed with concentrate feed supplied to the goats. Levucell ${ }^{\circledR}$ SB 20 (Saccharomyces cerevisiae type boulardii CNCM I-1079 2.0 $\times 1010$ colony-forming units (cfu)/g, Square Pharmaceuticals, Ltd. Bangladesh), was added as the yeast supplement in a concentrate at $1.5 \%$ of the total weight. Each animal was provided with $0.2 \mathrm{~kg}$ concentrate 
S. Saha et al.: Effects of yeast (Saccharomyces cerevisiae type boulardii CNCM I-1079) supplementation on growth performance and blood metabolites in Black Bengal goat kids

feed per day at the morning and afternoon feedings. In addition, each day $1 \mathrm{~kg}$ of German grass (Echinochloa polystachya) was supplied as fodder for each animal. The feeding schedule was established with concentrate and roughage twice daily (at $9.00 \mathrm{~h}$ and 16.00 h), and fresh water was given ad libitum. The ingredients and chemical composition of the experimental diet are reported in Table 1. The diets were formulated to meet NRC recommendations (NRC, 1985). The total experimental period was 50 days, with ten days' diet adaptation period. The selected animals were serially tagged in the neck region using a filament. All the animals were treated for internal and external parasites using Vermic (active ingredient: $10 \mathrm{mg} / \mathrm{ml}$ Ivermectin; dose $0.2 \mathrm{mg} / \mathrm{kg}$ body weight) 2 weeks before the experiment started. The animals were housed in individual cages $(2 \mathrm{~m} \times 1.5 \mathrm{~m})$ under a shed with a wooden roof for the entire period of the experiment.

Sampling and analysis. Daily feed intake and refusals were recorded; growth parameters (body weight, body length, height at withers, and heart girth) were recorded for every 10 day interval. Feed samples (concentrate and grass) were analyzed for chemical composition. Dry matter (DM), Crude protein (CP), Ether extract (EE) and Ash content were determined according to the standard procedure of the AOAC (1990). Neutral detergent fiber (NDF) and Acid detergent fiber (ADF) were analyzed according to the description of VAN SOEST et al. (1991) and VAN SOEST (1963).

Blood samples were collected on days 0 (start day) and 40 (end date) from the jugular vein of each animal, with the addition of anticoagulant (heparin) before the morning feeding. The blood samples were centrifuged and remained stored at $-20^{\circ} \mathrm{C}$ until analysis. Contents of blood urea, total protein, creatinine, cholesterol, total glyceride, cholesterol, glucose, Calcium $(\mathrm{Ca})$, Phosphorus $(\mathrm{P})$ and Magnesium $(\mathrm{Mg})$ in the serum were measured using an automated blood serum biochemical analyzer (Humalizer $\left.{ }^{\circledR}-3000\right)$. Glutamate oxaloacetate transaminase (GOT) and glutamate pyruvate transaminase (GPT) concentrations of blood samples were analyzed using a standard assay kit (Asan Pharma, Seoul, Korea).

Statistical analysis. The statistical analyses were performed in an R environment ( R Core Team, 2016). The data of growth parameters were analyzed using a mixed model with the formula:

$$
Y_{i j a k}=\mu+T_{i}+D_{j}+R_{\alpha}+e_{i j a k}
$$

where $Y_{i j a k}$ are the different growth measures ((Body weight, body length, height at withers, and heart girth); $\mu$ is the general mean; $T_{i}$ is the diet treatment ( $i=$ Control or Yeast); $D_{j}$ is the day of the measure $(j=0,10,20,30,40) ; R_{\alpha}$ is the random effect of the animal $a ; e_{i j a k}$ is random experimental error $\left(\operatorname{DNI} \sim\left(0, \sigma_{\varepsilon}^{2}\right)\right)$.

The blood parameters were analyzed using the same mixed model where $Y_{i j a k}$ are the different blood measures ( $\mathrm{Ca}, \mathrm{Mg}, \mathrm{P}$, glucose, creatinine, total protein, cholesterol, urea, 
S. Saha et al.: Effects of yeast (Saccharomyces cerevisiae type boulardii CNCM I-1079) supplementation on growth performance and blood metabolites in Black Bengal goat kids

GPT, GOT, total glyceride); $\mu$ is the general mean; $T_{i}$ is the treatment diet ( $i=$ Control or Yeast); $D_{j}$ is the day of the measurement ( $j=$ initial or final); $R_{\alpha}$ is the random effect of the animal $a$; $e_{i j a k}$ is the random experiment error $\left(\operatorname{DNI} \sim\left(0, \sigma_{\varepsilon}^{2}\right)\right.$ ). The mixed models were fitted with the package lme4 (BATES et al., 2015) and the least square means were estimated with the package lsmeans (LENTH, 2016) in the R environment.

\section{Results and discussion}

Growth performance. The effects of yeast supplementation compared to the control diet on the growth performance parameters of Black Bengal goat kids are presented in Table 2 and Fig. 1.

Table 2. Results of ANOVA ( $t$-value and significance), and variances for random effects for growth and blood variables of YS group compared with CD group

\begin{tabular}{|c|c|c|c|c|c|}
\hline \multirow[b]{2}{*}{ Trait } & \multicolumn{2}{|c|}{ Diet effect } & \multicolumn{3}{|c|}{ Variances } \\
\hline & $t$-value & $\mathrm{P}$-value & Animal & Residual & $\frac{\sigma_{\text {animal }}^{2}}{\sigma_{\text {total }}^{2}}$ \\
\hline \multicolumn{6}{|l|}{ Growth parameters: } \\
\hline Body weight, (kg) & -0.021 & 0.984 & 1.268 & 0.092 & 0.932 \\
\hline Body length, (cm) & -0.258 & 0.805 & 0.525 & 0.027 & 0.951 \\
\hline Height at withers, $(\mathrm{cm})$ & -1.162 & 0.289 & 0.415 & 0.073 & 0.850 \\
\hline Heart girth, $(\mathrm{cm})$ & 0.080 & 0.939 & 0.732 & 0.039 & 0.949 \\
\hline \multicolumn{6}{|l|}{ Blood metabolites: } \\
\hline Calcium, (mg/dL) & 4.047 & $0.006 * *$ & 0.375 & 2.375 & 0.136 \\
\hline Creatinine, $(\mathrm{mg} / \mathrm{dL})$ & -0.648 & 0.529 & 0.000 & 0.035 & 0.000 \\
\hline Glyceride, $(\mathrm{mg} / \mathrm{dL})$ & -1.899 & 0.106 & 0.558 & 10.09 & 0.052 \\
\hline Magnesium, (mg/dL) & 2.621 & $0.048^{*}$ & 0.040 & 0.172 & 0.188 \\
\hline Phosphorus, (mg/dL) & -0.283 & 0.787 & 0.286 & 2.105 & 0.119 \\
\hline Cholesterol, (mg/dL) & -0.069 & 0.947 & 11.180 & 104.200 & 0.096 \\
\hline Glucose, $(\mathrm{mg} / \mathrm{dL})$ & 1.501 & 0.198 & 8.485 & 15.320 & 0.356 \\
\hline Urea, (mg/dL) & -1.879 & 0.084 & 0.000 & 19.160 & 0.000 \\
\hline Protein, $(\mathrm{g} / \mathrm{L})$ & 1.681 & 0.143 & 9.090 & 10.150 & 0.472 \\
\hline${ }^{1} \mathrm{GPT},(\mathrm{IU} / \mathrm{L})$ & 0.365 & 0.721 & 0.000 & 29.100 & 0.000 \\
\hline${ }^{2} \mathrm{GOT},(\mathrm{IU} / \mathrm{L})$ & -0.456 & 0.656 & 0.000 & 341.300 & 0.000 \\
\hline
\end{tabular}

${ }^{1} \mathrm{GPT}=$ Glutamate pyruvate transaminase; ${ }^{2} \mathrm{GOT}=$ Glutamate oxaloacetate transaminase; Asterisks regard the significance of the difference $(* *=$ significant difference at $\mathrm{P}<0.01 ; *=$ significant difference at $\mathrm{P}<0.05$ )

There were no significant differences observed in body weight gain, heart girth, body length and height at withers between the CD and YS diet groups. The results agree with GOMES et al. (2014) who reported that body weights were not affected by dry yeast 
S. Saha et al.: Effects of yeast (Saccharomyces cerevisiae type boulardii CNCM I-1079) supplementation on growth performance and blood metabolites in Black Bengal goat kids

(S. cerevisiae) supplement in the diet. Also, live yeast (S. cerevisiae) supplementation has been described to have no influence on feed intake in terms of dry matter intake (DMI), daily live weight gain and final live weight gain in lambs (ISSAKOWICZ et al., 2013; MIKULEC et al., 2010; KAWAS et al., 2007). In contrast, some authors have found a positive result in animal growth performance parameters. KAMAL et al. (2013) found an improvement in DMI, body weight gain, height at withers and heart girth when live $S$. cerevisiae (NCDC-49) was supplemented in goat kids. Besides, HADADD and GOUSSOUS (2005) reported that body weight gain was higher with a yeast supplement diet compared with the control diet in finishing sheep. The differences between the present study and others could be explained by the size of the sample, the amount of yeast supplied and the study duration. Although beneficial effects of yeast on growth performance have been reported, there is considerable variability (TITI et al., 2008) in yeast supplement response related to the type of yeast, the amount of yeast supplemented, the type of forage fed and feeding strategy (MIKULEC et al., 2010).
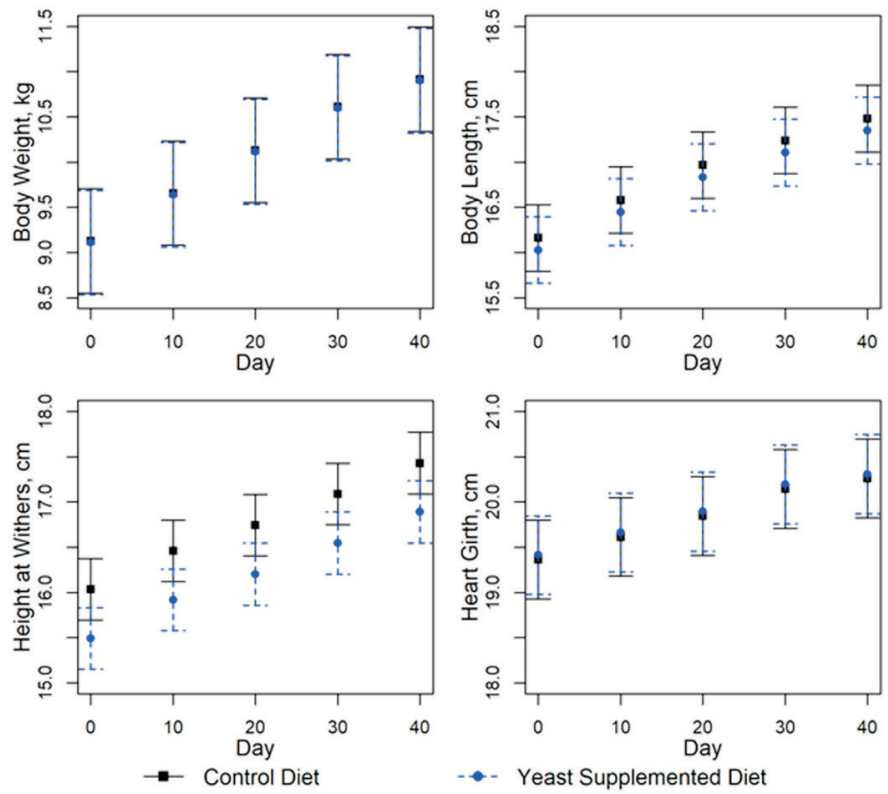

Fig. 1. Least square means \pm standard error for growth variables of Black Bengal goat kids fed control and yeast supplement diets. Asterisks regard the significance of the difference $(* *=$ significant difference at $\mathrm{P}<0.01 ; *=$ significant difference at $\mathrm{P}<0.05$ )

Blood metabolites. Results from ANOVA (T-Value and significance), and variances for random effects for blood parameters (calcium (Ca), creatinine, total glyceride, 
S. Saha et al.: Effects of yeast (Saccharomyces cerevisiae type boulardii CNCM I-1079) supplementation on growth performance and blood metabolites in Black Bengal goat kids

magnesium (Mg), phosphorus (P), cholesterol, glucose, urea, total proteins, GPT, GOT) of the YS group compared with the CD group are presented in Table 2 and Fig. 2. The major part of the variability was explained by residual variance, by the environment and effects not accounted for in the model. The effect of the animal for blood metabolites ranged from 0 to $47 \%$, average $12 \%$, indicating a minor effect of the animal compared to growth parameters. There was no significant difference in the concentration of any measured blood parameters between the YS and CD groups, except that the blood level concentrations of $\mathrm{Ca}$ and $\mathrm{Mg}$ for the YS group were higher $(\mathrm{P}<0.05)$ than those for the CD group. (Table 2; Fig. 2).
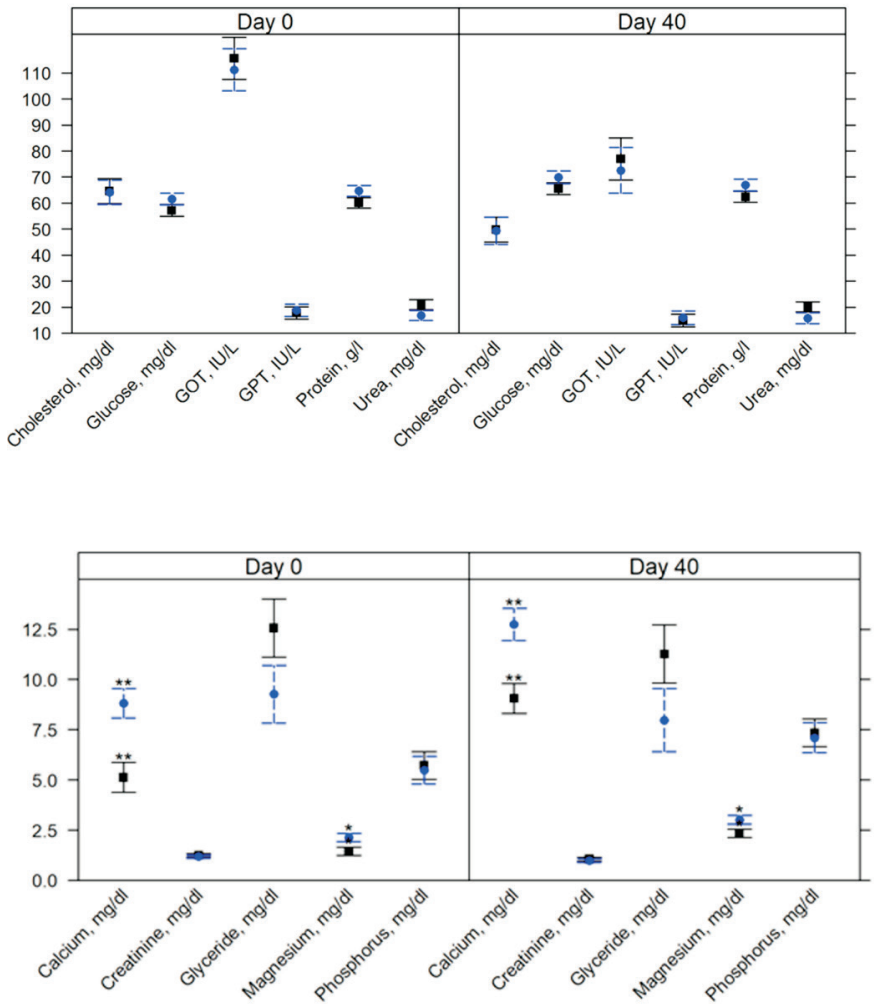

Fig. 2. Least square means \pm standard error for blood parameters of Black Bengal goat kids fed control and yeast supplement diets. GPT $=$ Glutamate pyruvate transaminase; GOT $=$ Glutamate oxaloacetate transaminase;Asterisks regard the significance of the difference $(* *=$ significant difference at $\mathrm{P}<0.01 ; *=$ significant difference at $\mathrm{P}<0.05$ ) 
However, the difference was observed at the beginning and at the end of the experiment, therefore, it is not possible to independently confirm that the yeast supplement affected the $\mathrm{Ca}$ and $\mathrm{Mg}$ absorption. BAGNICKA et al. (2014) found that YS improved the intestinal absorption of calcium in goats, similar to our study. Nevertheless, the mechanisms underlying the increased absorption of $\mathrm{Ca}$ are not fully elucidated (GILMAN and CASHMAN, 2006). YS in diet might help to colonize the healthy bacteria that produce short-chain fatty acids in the intestine, and consequently decrease the $\mathrm{pH}$ of the intestinal microenvironment (MATUR and ERASLAN, 2012). Therefore, calcium solubility increases which may be related to increased calcium absorption (GILMAN and CASHMAN, 2006; SCHOLZ-AHRENS et al., 2007). It could be the reason for findings of higher $\mathrm{Ca}$ level in the blood of the YS group compared to the $\mathrm{CD}$ group.

We found a significant $(\mathrm{P}<0.05)$ difference in blood level $\mathrm{Mg}$ concentrations in the $\mathrm{YS}$ group compared to the CD group at the end of the experiment. KOWALIK et al. (2016) found a similar tendency towards higher Mg concentrations in the YS group compared to the control group and also described that the composition of the diet might influence $\mathrm{mg}$ absorption. Usually, higher $\mathrm{Mg}$ absorption occurs during acidic fermentation in the intestine (YOUNES et al., 1996). The YS diet helps to increase the number of beneficial bacteria in the intestine and maintain the slightly acidic environment by increasing acidic fermentation activities in the intestine (MATUR and ERASLAN, 2012). The acidic environment facilitates higher intestinal absorption of Mg that leads to higher Mg levels in the blood. This might explain the reason for the higher Mg content in the blood. Urea and total protein concentrations in the blood were not affected by adding YS to the diet. These results are supported by the findings of TRIPATHI et al. (2008), where yeast supplementation did not affect urea concentration in the blood. Moreover, KOWALIK et al. (2016) found no effect of yeast supplementation on total protein concentration in the blood of lambs. Also, no effect was found from yeast supplementation on cholesterol and total glycerides in blood serum. Contrary to the results of the present study, KOWALIK et al. (2016) found a higher concentration of total cholesterol and triacylglycerols from a live yeast supplement diet in lambs. According to BAUCHART (1993) cholesterol concentration in the blood depends on age, physiological state and diet, particularly the total lipid content in the diet. The findings of this study for GOT and GPT agree with the findings of PIVA et al. (1993) who demonstrated that yeast did not affect hepatic function or enzyme activities. The activities of some liver enzymes GPT and GOT in the serum are generally considered as indicators of some pathological changes to tissues and organs.

\section{Conclusions}

It may be concluded that yeast (Saccharomyces cerevisiae type boulardii CNCM I-1079) added to the diet of growing Black Bengal goat kids slightly increased Ca and $\mathrm{Mg}$ concentration levels in their blood. However, yeast supplement did not influence 
S. Saha et al.: Effects of yeast (Saccharomyces cerevisiae type boulardii CNCM I-1079) supplementation on growth performance and blood metabolites in Black Bengal goat kids

growth performance and other blood parameters over the short time period of 40 days. Further studies under different feeding conditions, with larger sample size and different age groups of animals will help to clarify the influence of yeast supplementation in the diets of Black Bengal goat kids.

\section{Acknowledgements}

We are grateful to the Square Pharmaceuticals Ltd., Bangladesh for providing the yeast (Levucell ${ }^{\circledR}$ SB 20 (Saccharomyces cerevisiae type boulardii CNCM I-1079 2.0×1010 colony-forming units (cfu)/g)).

\section{References}

AHMED, M. H., M. M. Y. ELGHANDOUR, A. Z. M. SALEM, H. S. ZEWEIL, A. E. KHOLIF, A. V. KLIEVE, A. M. A. ABDELRASSOL (2015): Influence of Trichoderma reesei or Saccharomyces cerevisiae on performance, ruminal fermentation, carcass characteristics and blood biochemistry of lambs fed Atriplexnummularia and Acacia saligna mixture. Livest Sci. 180, 90-97.

DOI: 10.1016/j.livsci.2015.06.019

AMIN, M. R., S. S. HUSAIN, A. B. M. M. ISLAM (2000): Evaluation of Black Bengal goats and their cross with the Jamunapari breed for carcass characteristics. Small Ruminant Res. 38, 211-215.

DOI: $10.1016 / \mathrm{s} 0921-4488(00) 00165-6$

AOAC. 1990: Official Methods of Analysis. 15th ed. Assoc. Off. Anal. Chem., Arlington, VA.

BAGNICKA, E., J. JARCZAK, J. KABA, A. JÓ̊̊WIK, M. CZOPOWICZ, N. STRZALKOWSKA, J. KRZYÅEWSKI (2014): Active dry yeast culture supplementation effect on the blood biochemical indicators of dairy goats. J. Adv. Dairy Res. 2, 1-7.

DOI: $10.4172 / 2329-888 X .1000123$

BATES, D., M. MÄCHLER, B. BOLKER, S. WALKER. (2015): Fitting Linear Mixed-Effects Models Using lme4. J. Stat. Softw. 67, 1-48.

DOI: $10.18637 /$ jss.v067.i01

BAUCHART, D. (1993): Lipid absorption and transport in ruminants. J. Dairy Sci. 76, 3864-3881. DOI:10.3168/jds.s0022-0302(93)77728-0

CABRERA, E. J. I., M. G. D. MENDOZA, I. E. ARANDA, C. GARCIA-BOJALIL, G. R. BARCENA, J. J. A. RAMOS (2000): Saccharomyces cerevisiae and nitrogenous supplementation in growing steers grazing tropical pastures. Anim Feed Sci. Technol. 83, 4955.

DOI: $10.1016 / \mathrm{s} 0377-8401(99) 00109-1$

DOBICKI, A., J. PREŚ, A. ZACHWIEJA, R. MORDAK, W. JAKUS (2007): Influence of yeast preparations on chosen biochemical blood parameters and the composition of cow milk. Med Weter. 63, 951-954. 
S. Saha et al.: Effects of yeast (Saccharomyces cerevisiae type boulardii CNCM I-1079) supplementation on growth performance and blood metabolites in Black Bengal goat kids

GILMAN, J., K. D. CASHMAN (2006): The effect of probiotic bacteria on transepithelial calcium transport and calcium uptake in human intestinal-like Caco-2 cells. Intest. Microbiol. 7, 1-5.

GOMES, L. C., C. R. AlCALDE, L. R. D. LIMA, L. S. D., LIMA, R. D. SOUZA, A. P. S. POSSAMAI (2014): Nutritive value of diets containing inactive dry yeast for lactating Saanen goats. R. Bras. Zotec. 43, 36-43.

HADDAD, S. G., S. N. GOUSSOUS (2005): Effect of yeast culture supplementation on nutrient intake, digestibility and growth performance of Awassi lambs. Anim. Feed Sci. Technol. 118, 343-348.

DOI: 10.1016/j.anifeedsci.2004.10.003

HILLAL, H., G. EL-SAYAAD, M. ABDELLA (2011): Effect of growth promoters (probiotics) supplementation on performance, rumen activity and some blood constituents in growing lambs. Arch. Tierzucht. 6, 607-617

ISSAKOWICZ, J., M. S. BUENO, A. C. K. SAMPAIO, K. M. R. DUARTE (2013): Effect of concentrate level and live yeast (Saccharomyces cerevisiae) supplementation on Texel lamb performance and carcass characteristics. Livest. Sci. 155, 44-52.

DOI: $10.1016 /$ j.livsci.2013.04.001

KAMAL, R., T. DUTT, M. SINGH, D. N. KAMRA, M. PATEL, L. C. CHOUDHARY, N. AGRAWAL, S. KUMAR, M. ISLAM (2013): Effect of live Saccharomyces cerevisiae (NCDC-49) supplementation on growth performance and rumen fermentation pattern in local goat. J. Appl. Anim. Res. 41, 285-288.

DOI: $10.1080 / 09712119.2013 .782865$

KAWAS, J. R., R. GARCÍA-CASTILLO, H. FIMBRES-DURAZO, F. GARZA-CAZARES, J. F. G. HERNÁNDEZ-VIDAL, E. OLIVARES-SÁENZ, C. D. LU (2007): Effects of sodium bicarbonate and yeast on nutrient intake, digestibility, and ruminal fermentation of lightweight lambs fed finishing diets. Small Ruminant Res. 67, 149-156.

DOI: 10.1016/j.smallrumres.2005.09.010

KOWALIK, B., J. SKOMIAL, R. MILTKO, M. MAJEWSKA (2016): The effect of live Saccharomyces cerevisiae yeast in the diet of rams on the digestibility of nutrients, nitrogen and mineral retention, and blood serum biochemical parameters. Turk. J. Vet. Anim. Sci. 40, 534-539.

DOI: $10.3906 / V E T-1511-37$

LENTH, R. V. (2016): Least-Squares Means: The R Package 1smeans. J. Stat. Softw. 69, 1-33. DOI: $10.18637 /$ jss.v069.i01

MATUR, E., E. ERASLAN (2012): The impact of probiotics on the gastrointestinal physiology. INTECH Open Access Publisher. p. 60.

MIKULEC, Ž., T. MAŠEK, B. HABRUN, H. VALPOTIĆ (2010): Influence of live yeast cells (Saccharomyces cerevisiae) supplementation to the diet of fattening lambs on growth performance and rumen bacterial number. Vet. arhiv 80, 695-703. 
S. Saha et al.: Effects of yeast (Saccharomyces cerevisiae type boulardii CNCM I-1079) supplementation on growth performance and blood metabolites in Black Bengal goat kids

MILEWSKI, S (2009): Effect of yeast preparations Saccharomyces cerevisiae on meat performance traits and blood hematological indices in sucking lambs. Med. Weter. 65, 51-54.

NRC (1985). Nutrient Requirements of Sheep. $6^{\text {th }}$ rev. ed. Natl. Acad. Press, Washington, DC.

PIVA, G., S. BELLADONNA, G. FUSCONI, F. SICBALDI (1993): Effects of yeast on dairy cow performance, ruminal fermentation, blood components, and milk manufacturing properties. J. Dairy Sci. 76, 2717-2722.

R CORE TEAM (2016): R: A Language and Environment for Statistical Computing. R Found. Stat. Comput. 1, 409.

SCHOLZ-AHRENS, K. E., P. ADE, B. MARTEN, P. WEBER, W. TIMM, Y. AEIL, C. C. GLÜER, J. SCHREZENMEIR (2007): Prebiotics, probiotics, and synbiotics affect mineral absorption, bone mineral content, and bone structure. J. Nutr. 137, 838- 846.

SULTANA, S., M. J. KHAN, M. R. HASSAN, M. A. M. Y. KHONDOKER (2012): Effects of concentrate supplementation on growth, reproduction and milk yield of Black Bengal goats (Capra hircus). The Bang Vet. 29, 7-16.

TITI, H. H., R. O. DMOUR, A. Y. ABDULLAH (2008): Growth performance and carcass characteristics of Awassi lambs and Shami goat kids fed yeast culture in their finishing diet. Anim. Feed Sci. Technol. 142, 33-43.

TRIPATHI, M. K., S. A. KARIM, O. H. CHATURVEDI, D. L. VERMA (2008): Effect of different liquid cultures of live yeast strains on performance, ruminal fermentation and microbial protein synthesis in lambs. J. Anim. Physiol. Anim. Nutr. 92, 631-639.

VAN SOEST, P. J., J. B. ROBERTSON, B. A. LEWIS (1991): Methods for dietary fiber, neutral detergent fiber, and nonstarch polysaccharides in relation to animal nutrition. J. Dairy Sci. 74, 3583-3597.

DOI: $10.3168 /$ jds.s0022-0302(91)78551-2

VAN SOEST, P. J. (1963): Use of detergents in the analysis of fibrous feeds. 2. A rapid method for the determination of fiber and lignin. The Journal of AOAC. 46, 829-835.

WEHNER, G. R., L. BROKAW, J. E. GAMETT, J. ZIDON (1998): Effect of yeast culture inclusion in ad libitum trace mineralized salt on cow and calf performance. J. Anim. Sci. (Suppl. 1), 34.

YOUNES, H., C. DEMIGNÉ, C. RÉMÉSY (1996): Acidic fermentation in the caecum increases absorption of calcium and magnesium in the large intestine of the rat. Br. J. Nutr. 75, 301-314. 
S. Saha et al.: Effects of yeast (Saccharomyces cerevisiae type boulardii CNCM I-1079) supplementation on growth performance and blood metabolites in Black Bengal goat kids

\section{SAHA, S., S. SINGHA, S. S. U. AHMED, H. TOLEDO-ALVARADO, M. M. H. KHAN: Učinci dodatka kvasca (Saccharomyces cerevisiae tipa boulardii CNCM I-1079) na rast i metabolita krvi jaradi crne bengalske pasmine. Vet. arhiv 88, 661- $672,2018$.}

\section{SAŽETAK}

Cilj rada bio je istražiti učinke kvasca (Saccharomyces cerevisiae tipa boulardii CNCM I-1079) na rast i metabolite krvi kod jaradi crne bengalske pasmine. Eksperiment je proveden na osam jarića podijeljenih u kontrolnu skupinu (KS), koja nije dobivala kvasac, i eksperimentalnu skupinu (ES), kojoj je u obrok dodavano $1,5 \%$ kvasca. Pokus je trajao 40 dana tijekom kojih su učinci rasta mjereni svakih deset dana, a uzorci krvi prikupljeni su nulti i 40. dan eksperimenta. Podaci su analizirani pomoću miješanog modela. Rezultati su pokazali da kvasac nema učinka na pokazatelje rasta. Štoviše, dodavanje kvasca u prehranu nije utjecalo na pokazatelje u krvi (fosfor - P, kolesterol, triacilglicerol, ureju, ukupni protein, glutamat-piruvatnu transaminazu - GPT i glutamat-oksaloacetatnu transaminazu - GOT), uz izuzetak kalcija (Ca) i magnezija (Mg). U eksperimentalnoj skupini životinja opaženo je neznatno povećanje koncentracije Ca i Mg u krvi u odnosu na životinje u kontrolnoj skupini.

Ključne riječi: Saccharomyces cerevisiae tip boulardii; pokazatelji rasta; pokazatelji u krvi; jarad 